\title{
Izobrazba, splošna stališča do cepljenja ter namera za cepljenje proti gripi in covidu-ı9 v Sloveniji: analiza štirih anketnih vzorcev
} Andrej Kirbišs, Monika Lamot

\section{Uvod}

\begin{abstract}
Cepiva so ena najpomembnejših pridobitev napredka znanosti in medicine (Novella, 2007; Orenstein in Ahmed, 2017), ki so po nekaterih ocenah globalno rešila več kot eno milijardo življenj (Ratej in Muršič, 2020; World Economic Forum, 2020), pri čemer bolj kot cepljenje zmanjša breme nalezljivih bolezni zgolj dostop do pitne vode (Andre et al., 2008). Kljub napredku znanosti in široki uporabi cepiv pri soočanju z nalezljivimi boleznimi, preprečljivih s cepljenjem, ter reševanju življenj množic po vsem svetu so v zadnjih desetletjih nekateri vidiki ekonomskega in družbenega napredka - predvsem v zahodnih družbah - pripeljali do nezaželenih posledic, med drugim do naraščajočega nezaupanja in zavračanja cepiv (ibid.). Gre za pojav oklevanja pred cepljenjem, ki se nanaša na skupine ljudi, ki do cepljenja izražajo zadržke oziroma dvom (MacDonald, 2015). Nezaupanje v cepiva - pa tudi v znanost, medicino, strokovnjake in institucije - se v zadnjih letih paradoksalno krepi $z$ naraščanjem izobrazbenih ravni prebivalcev po vsem svetu. $V$ pričujoči raziskavi smo preučili vlogo posameznikove izobrazbe pri izoblikovanju stališča glede cepljenja in na sprejemanje cepiv v Sloveniji. Osredotočili smo se na povezavo izobrazbe s splošnimi stališči do cepljenja v letih 2019 in 2020, s stališči do cepljenja proti gripi in covidu-19 v letu 2020 in na vlogo izobrazbe pri nekaterih znanih dejavnikih stališč do cepljenja v letih 2016, 2019 in 2020.
\end{abstract}


$\mathrm{V}$ naslednjem podpoglavju prispevka najprej predstavimo oklevanje pred cepljenjem in stališča do cepljenja, dejavnike stališč ter vlogo izobrazbe. Na podlagi pregleda nato zastavimo namen pričujoče raziskave, predstavimo vzorce in merske instrumente treh študij, temu pa sledi predstavitev ključnih ugotovitev. V zadnjem delu prispevka razpravljamo o implikacijah naših ugotovitev in omejitvah naše raziskave ter podamo priporočila za prihodnje raziskave in predloge ukrepov za odločevalce.

\section{Stališča javnosti do cepiv in cepljenja}

Oklevanje pred cepljenjem ni nov pojav, saj ima t. i. proticepilsko gibanje dolgo zgodovino (Lamot, 2020), se pa $\mathrm{v}$ zadnjih desetletjih nezaupanje $\mathrm{v}$ cepiva širi med vse širše segmente populacije, tudi iz nacionalnih na globalne ravni, predvsem zaradi porasta IKT (informacijsko-komunikacijske tehnologije) (Blume, 2006; Wolfe in Sharp, 2002). Oklevanje pred cepljenjem tako predstavlja eno izmed desetih največji globalnih groženj javnemu zdravju (WHO, 2019), njegova razširjenost med državami pa se razlikuje. Primerjalne analize kažejo, da prebivalci ekonomsko bolj razvitih držav v povprečju izkazujejo višjo stopnjo pozitivnih stališč do cepiv, a je denimo $\mathrm{v}$ skupini desetih držav $\mathrm{z}$ največjim deležem negativnih stališč do cepljenja sedem iz evropske regije (Larson et al., 2016). Ob tem nizko zaupanje v varnost cepiv izkazujejo tudi prebivalci postkomunističnih evropskih držav, npr. BiH, Rusije, Ukrajine in Slovenije (ibid.).

Problem nezaupanja v cepiva ima ne le pomembne zdravstvene, temveč tudi družbene in ekonomske posledice. $\mathrm{V}$ zadnjih letih se v različnih državah sveta pojavljajo primeri, ko se zaradi zavračanja cepljenja $\mathrm{v}$ določenih segmentih javnosti ponovno pojavljajo nekatere nalezljive bolezni, ki so bile praktično izkoreninjene (Bloom et al., 2005). Ob tem lahko oklevanje pred cepljenjem predstavlja tudi globalni problem $\mathrm{v}$ času aktualne pandemije covida-19, še posebej v državah, kjer imajo prebivalci do cepiv najbolj skeptična stališča.

Slovenija velja za eno izmed držav z visoko stopnjo oklevanja pred cepljenjem med njenim prebivalstvom. Čeprav so po eni strani spodbudni rezultati, da je interes za cepljenje proti covidu-19 v nekaj dneh izrazilo več kot šestdeset tisoč $(2,88 \%)$ prebivalcev Slovenije (eUprava), pa epidemiologi in imunologi poudarjajo, da je za zatrtje epidemije potreben visok delež precepljenosti, ki se giblje med $60 \%$ in 70 \% (Fontanet in Cauchemez, 2020). Javnomnenjske raziskave v Sloveniji kažejo na eno največjih stopenj oklevanja pred cepljenem proti covidu-19 v svetu, saj izrazito velik delež 
državljanov pravi, da se ne namerava cepiti oz. je delež takih celo višji od tistih, ki se proti covidu-19 nameravajo cepiti (Mediana, 2020). Ob tem je zaskrbljujoče tudi dejstvo, da se je oklevanje pred cepljenjem v Sloveniji tekom leta 2020 celo povečevalo. V Sloveniji je javnomnenjska anketa v juniju 2020 pokazala, da bi se bilo pripravljenih cepiti $55 \%$ Slovencev, v oktobru 2020 je delež padel na zgolj $35 \%$ (Mediana, 2020), v novembru pa je pripravljenost za cepljenje izrazilo 43 \% Slovencev (Valicon, 2020). Navedeni deleži so za uspešen boj proti epidemiji z doseganjem kolektivne imunosti prenizki. Oklevanje pred cepljenjem je v Sloveniji bilo najvišje ravno v drugem valu epidemije, ko je imela država eno najslabših epidemioloških slik na svetu z visoko stopnjo okuženih in umrljivosti (OurWorldinData, 2020). Da je odklanjanje cepiva proti covidu-19 v Sloveniji visoko, sicer ne bi smelo biti presenečenje, glede na to, da so se prebivalci Slovenije v okviru meddržavnih analiz zaupanja $\mathrm{v}$ pomembnost, varnost in učinkovitost cepiv, ki so bile izvedene še pred pandemijo, uvrščali na dno lestvic držav (Larson et al., 2016) in glede na ugotovitve najnovejših raziskav, da so v Sloveniji splošna stališča do cepljenja najmočnejši napovedovalec stališč do cepljenja proti covidu-19 (Kirbiš et al., 2020).

\section{Izobrazba kot dejavnik splošnih stališč in dejavnikov stališč do cepljenja}

Ena novejših meddržavnih raziskav stališč do cepiv in cepljenja (Eurobarometer, 2019) pred pandemijo covid-19 je analizirala prebivalce držav EU28, tj. osemindvajseterice držav Evropske Unije. Rezultati Eurobarometra so sicer pokazali, da so imeli Evropejci v letu 2019 razmeroma visoko stopnjo ozaveščenosti in na splošno pozitiven odnos do cepljenja, a da obstajajo precejšnje razlike v znanju in vedenju med državami in med sociodemografskimi skupinami. Poročilo raziskave med drugim oriše tudi praviloma pozitivno vlogo izobrazbe: bolj izobraženi Evropejci so denimo bolj verjetno cepljeni ali imajo cepljenega družinskega člana, prav tako pa se v večji meri strinjajo, da so cepiva učinkovita. Več kot polovica (54 \%) Evropejcev $\mathrm{v}$ najbolj izobraženi skupini ima višjo raven znanja o cepivih v primerjavi z manj kot štirimi od desetih (39 \%) Evropejcev, ki so v najnižji izobrazbeni skupini. Hkrati pa je na vprašanje: „Če bi potrebovali informacije o cepljenju, na katerega od naslednjih virov bi se obrnili?« najbolj izobražena skupina v večji meri odgovorila, da bi se obrnila tudi na spletna družbena omrežja in na druga spletna mesta kot najmanj izobražena skupina (ibid.), kar lahko predstavlja težavo pri sprejemanju cepljenja, saj sta se zaupanje 
v spletna socialna omrežja in njihova uporaba v drugih raziskavah izkazala za povezana $z$ večjim oklevanjem pred cepljenjem (Hoffman et al., 2019). V poročilu Eurobarometra sicer niso prikazane meddržavne razlike glede vloge izobrazbe pri stališčih do cepiva. Številne druge raziskave kažejo tudi bolj problematični učinek vloge izobrazbe pri stališčih do cepiv. Krepitev gospodarske, družbene in politične razvitosti v zahodnih družbah gotovo sloni na tehnološkem in znanstvenem napredku. Povprečna raven izobrazbe se je v zadnjih desetletjih po svetu močno povečala, kar pa je, paradoksalno, na področju stališč do cepiv s seboj prineslo tudi nekatere negativne posledice. Po eni strani višanje izobrazbenih ravni pomeni ne le višjo zdravstveno ozaveščenost, ampak tudi izboljšan dostop do informacij skozi množične medije, postmoderna družba oz. »družba znanja « pa preko socioekonomskega napredka mobilizira kognitivne kompetence množic (Inglehart in Welzel, 2005), a raziskave kažejo, da lahko višje ravni izobrazbe v bolj razvitih družbah predstavljajo tudi pomembno oviro pri zaupanju ljudi v učinkovitost in varnost cepiv (Endrich et al., 2009).

Kako je mogoče razložiti negativen učinek izobrazbe na preventivna zdravstvena vedenja, vključno $\mathrm{z}$ nezaupanjem $\mathrm{v}$ cepiva? Visoka socioekonomska razvitost, krepitev zdravstvenih sistemov ter obsežni in učinkoviti programi cepljenja so v zahodnih družbah praktično izkoreninili številne bolezni, ki jih je mogoče preprečiti s cepivi, kar je zmanjšalo zaznano grožnjo nalezljivih bolezni v javnosti in, paradoksalno, povečalo oklevanje pred cepivi (Champion in Sugg Skinner, 2008; Healy, 2014; Edwards in Hackell, 2016). Eden izmed mehanizmov odnosa med višjo izobrazbo in drugimi viri ter skepso do cepiv je tudi "zdravizem« (angl. healthism). Crawford (1980) ga definira kot "prepričanja, vedenja in pričakovanja artikuliranih, zdravstveno ozaveščenih in informacijsko bogatih « družbenih skupin z višjim socioekonomskim statusom (Greenhalgh in Wessely, 2004). V zadnjih letih si pripadniki socialno privilegiranih družbenih skupin prizadevajo v čim večji meri nadzirati lastno zdravstveno vedenje $\mathrm{z}$ namenom izboljšanja svojega zdravja. Te skupine zaznavajo nizke percepcije tveganja pri boleznih, preprečljivih s cepivi, hkrati pa imajo višje percepcije (potencialnih) tveganj, ki jih predstavlja tehnološki in medicinski napredek, vključno s cepivi, in posledično razvijajo nezaupanje v znanost in medicino, znanstvene ugotovitve in prakse (Beck, 1992; Bocquier et al., 2017). V Franciji denimo zdravizem v celoti pojasni (mediira) povezavo med višjo izobrazbo in oklevanjem pri cepljenju (Bocquier et al., 2018). Visoko izobraženi starši so denimo glede cepljenja svojih otrok prepričani, da jim nji- 
hova visoka izobrazba omogoča sprejemanje pravilnih in tehtnih odločitev glede cepljenja, ob tem pa socialno privilegirani starši v večji meri dvomijo $\mathrm{v}$ in preizprašujejo konvencionalne vire zdravstvenih informacij (Swaney in Burns, 2019).

Tudi v Sloveniji raziskave kažejo, da izobrazba nima enoznačnega učinka na stališča do cepljenja. Lamot (2020) je v raziskavi analize podatkov Slovenskega javnega mnenja (SJM 2016/1) ugotovila, da izobrazba ob kontroli sociodemografskih in socioekonomskih dejavnikov ni statistično značilen dejavnik stališč do cepljenja. Še več, na nereprezentativnem vzorcu je pri analizi kontinuuma stališč - od tistih, ki zavračajo vsa cepiva, do tistih, ki jih v celoti sprejemajo - ugotovila, da so v skupini tistih, ki sprejemajo cepiva, bolj verjetno nižje izobraženi. Rezultati tujih raziskav v času pandemije covida-19 sicer kažejo na pozitivne učinke izobrazbe. Bolj izobraženi posamezniki $\mathrm{v}$ večji meri sledijo priporočilom preventivnih in samozaščitnih vedenj (nošenje zaščitnih mask, socialno distanciranje, pogosto umivanje rok, izogibanje množicam ipd.) (Jehn in Zajacova, 2020; Kavanagh et al., 2020), hkrati pa izražajo bolj pozitivna stališča do cepljenja proti covidu-19 (Malik et al., 2020; J. K. Ward et al., 2020).

Ob tem izobrazba ni povezana zgolj s stališči do cepljenja, ampak lahko učinkuje tudi na nekatere pomembne dejavnike stališč do cepljenja. Pretekle raziskave so pokazale, da oklevanje pred cepljenjem med drugim zvišujejo neznanje o cepivih in cepljenju (Martinello et al., 2003; Betsch in Wicker, 2012; Zingg in Siegrist, 2012), nizke percepcije tveganja (nalezljivosti in nevarnosti) nalezljive bolezni (Byrne et al., 2012; Elizondo-Alzola et al., 2020), nezaupanje $\mathrm{v}$ zdravstvene institucije, zaposlene $\mathrm{v}$ zdravstvu in v zdravstveni sistem (Gallup, 2019; Lalumera, 2018; Rozbroj et al., 2019), višje zaupanje $\mathrm{v}$ komplementarno in alternativno medicino (Browne et al., 2015; Hoffman et al., 2019) ter strinjanje s prepričanji, povezanimi s teorijami zarot (Jolley in Douglas, 2014; Hornsey et al., 2018; Ekram et al., 2019).

Navedeni dejavniki so z izobrazbo nekonsistentno povezani. Lamot in (Lamot et al., 2021) so denimo na nereprezentativnem vzorcu Slovencev ugotovili, da so anketiranci v srednji izobrazbeni kategoriji izkazovali najnižje znanje o cepivih, ob tem pa so tisti, ki so bili trenutno vključeni v izobraževanje (dijaki in študenti), izkazovali višje znanje o cepivih od zaposlenih in brezposelnih. Na drugi strani je na ravni Evrope že omenjena raziskava Eurobarometer (Eurobarometer, 2019b) ugotovila večje znanje o cepivih pri bolj izobraženih Evropejcih. Dryhurst in sodelavci (2020) so denimo preučili percepcije tveganja glede covida-19 v desetih državah sve- 
ta iz Amerike, Evrope in Azije in ugotovili, da izobrazba ni bila povezana s percepcijami tveganja v nobeni izmed analiziranih držav. Zaupanje v komplementarno in alternativno medicino je prav tako višje med bolj izobraženimi (van der Schee in Groenewegen, 2010). Ker navedeni dejavniki predstavljajo pomembno vlogo pri stališčih do cepljenja, je potrebno preučiti, ali so v Sloveniji ti dejavniki stališč povezani z izobrazbenimi ravni posameznika.

\section{Namen}

Namen naše raziskave je bil preučiti, kako je v Sloveniji izobrazba povezana: 1) s splošnimi stališči do cepljenja; 2) z namero za cepljenje proti gripi in covidu-19 in 3) $\mathrm{z}$ dejavniki stališč do cepljenja. $\mathrm{V}$ ta namen smo izvedli tri študije. V prvi smo na štirih vzorcih prebivalcev Slovenije analizirali odnos med izobrazbo, stališči in dejavniki stališč do cepljenja, in sicer v Študiji 1 na enem reprezentativnem vzorcu v letu 2019 (Eurobarometer, 2019a) ter enem nereprezentativnem vzorcu (Lamot in Kirbiš, 2020), v Študiji 2 na enakem nereprezentativnem vzorcu (Lamot in Kirbiš, 2020) in v Študiji 3 na štirih vzorcih - poleg dveh že omenjenih še na reprezentativnem vzorcu Slovenskega javnega mnenja (Kurdija et al., 2016) in na nereprezentativnem vzorcu v letu 2019 (Lamot in Kirbiš, 2019).

\section{Vključene študije}

\section{Študija 1: Izobrazba in splošna stališča do cepljenja v letih 2019 in 2020}

\section{Vzorci in merski instrumenti}

Vzorec raziskave Eurobarometer je bil sestavljen iz 15-letnikov ter starejših iz 28-ih držav Evropske unije. Reprezentativni podatki so bili v Sloveniji zbrani v marcu leta $2019\left(\mathrm{~N}=1.016 ; 56,8 \%\right.$ žensk; $M_{\text {starost }}=52,17$ leta) (Eurobarometer, 2019b). V raziskavi o stališčih do cepljenja proti covidu-19 (Lamot in Kirbiš, 2020) je vzorec sestavljalo 851 oseb, od tega 84,5 \% žensk. V raziskavo so se vključili udeleženci, stari od 18 do 63 let; povprečna starost je bila 33,2 leta. Slaba tretjina (31,4 \%) udeležencev je imela zaključeno srednješolsko izobrazbo ali manj, 34,9 \% je imelo dodiplomsko izobrazbo do vključno 1 . bolonjske stopnje, $33,6 \%$ pa jih je imelo dokončan študij 2 . bolonjske stopnje ali višje. 
S podatki Eurobarometra smo splošna stališča merili s štirimi trditvami: "Za vse je pomembno, da opravijo obvezna cepljenja«, »Necepljenje lahko povzroči hude zdravstvene težave«, "Cepljenje je pomembno zato, da zaščitite ne le sebe, ampak tudi druge « in »Cepljenje drugih oseb je pomembno za zaščito tistih, ki se ne morejo cepiti (npr. novorojenčkov, oseb z oslabljenim imunskim sistemom ali hudo bolnih ljudi)«. Trditve so bile merjene na 4 -stopenjski Likertovi lestvici $(1=$ se sploh ne strinjam; $4=$ se popolnoma strinjam). Izdelali smo sumacijsko spremenljivko z zadostno zanesljivostjo (Cronbachov $\alpha=0,85$ ).

V raziskavi o stališčih do cepljenja proti covidu-19 smo generalno stališče do cepljenja merili z naslednjim vprašanjem: »Ali bi v splošnem rekli, da imate zadržke v zvezi s cepljenjem proti nalezljivim boleznim (npr. otroška cepiva)? (o = sploh nimam zadržkov; 10 = imam veliko zadržkov). Izobrazbo smo merili na tristopenjski lestvici ( 1 - srednješolska izobrazba ali manj; 2 - dodiplomska izobrazba do vključno 1. bolonjske stopnje; 3 - dokončana 2. bolonjska stopnja ali višje).

\section{Rezultati}

Rezultati analiz podatkov Eurobarometra (2019) so ob kontroli spola in starosti pokazali, da med izobrazbo in stališči do cepljenja ni statistično značilne povezave $(\mathrm{p}>0,05)$. Tudi analize podatkov nereprezentativnega vzorca (Lamot in Kirbiš, 2020) so ob kontroli spola in starosti pokazale, da med izobrazbo in stališči do cepljenja ni statistično značilne povezave ( $\mathrm{p}>0,05)$.

\section{Študija 2: Izobrazba in stališča do cepljenja proti gripi in covidu-19 $v$ letu 2020}

\section{Vzorci in merski instrumenti}

Analizirali smo anketne podatke glede stališč do cepljenja proti gripi in covidu-19 (Lamot in Kirbiš, 2020) ${ }^{\mathrm{I}}$, uporabljena je bila enaka spremenljivka izobrazbene stopnje. V merski instrument stališč do cepljenja smo vključili namero za cepljenje proti dvema nalezljivima boleznima. Vprašanji sta se glasili: »Kolikšna je verjetnost, da bi se cepili proti sezonski gripi?» in »Kolikšna je verjetnost, da bi se cepili proti koronavirusu, če bi bilo cepivo na voljo? $(\mathrm{o}=$ sploh ni verjetno; 10 = zelo verjetno). 


\section{Rezultati}

Rezultati so ob kontroli spola in starosti pokazali, da med izobrazbo in namero cepljenja proti gripi in proti covidu-19 ni statistično značilne povezave $(\mathrm{p}>0,05)$.

\section{Študija 3: Izobrazba in dejavniki stališč do cepljenja v letih 2016,} 2019 in 2020

\section{Vzorci in merski instrumenti}

V Študiji 3 smo analizirali podatke štirih vzorcev: Slovensko javno mnenje 2016/1 (Kurdija et al., 2016), Eurobarometer (Eurobarometer, 2019b), Stališča do cepljenja (Lamot in Kirbiš, 2019) in Stališča do epidemije covida-19 (Lamot in Kirbiš, 2020). Zanimalo nas je, ali so nekateri v tujih raziskavah ugotovljeni dejavniki stališč do cepljenja tudi v Sloveniji povezani z izobrazbeno stopnjo. V okviru Študije 1 in Študije 2 smo že opisali vzorec raziskave Eurobarometer (Eurobarometer, 2019b) in vzorec raziskave Stališča do epidemije covida-19 (Lamot in Kirbiš, 2020), na tem mestu dodajamo še opisa preostalih dveh vzorcev.

Reprezentativni vzorec prebivalcev Slovenije SJM 2016/1 (Kurdija et al., 2016) so sestavljale polnoletne osebe $(n=1070)$, od tega $47,4 \%$ moških. Povprečna starost udeležencev je bila 55,1 leta. Največ udeležencev je imelo srednješolsko izobrazbo (31,8 \%). V raziskavi o stališčih do cepljenja v 2019 (Lamot in Kirbiš, 2019) je vzorec sestavljalo 661 respondentov, od tega $76 \%$ žensk. V raziskavo so bili vključeni udeleženci, stari od 18 do 72 let; povprečna starost udeležencev je bila 34,9 leta. 29,7 \% udeležencev je imelo zaključeno srednješolsko izobrazbo ali manj, 31,8 \% jih je imelo dodiplomsko izobrazbo do vključno 1. bolonjske stopnje, 38,6 \% pa jih je imelo dokončan študij 2. bolonjske stopnje ali višje.

$\mathrm{V}$ raziskavi SJM 2016/1 smo analizirali naslednje dejavnike stališč do cepljenja: oceno zdravstvenega sistema v Sloveniji (»Kakšno je po vašem mnenju splošno stanje šolstva danes v Sloveniji?« (o = izjemno slabo; $10=$ izjemno dobro)), oceno kvalitete zdravstvenih storitev za otroke in odrasle v kraju respondenta (»Ocenite kvaliteto zdravstvenih storitev za odrasle v vašem kraju « ( 1 = zelo slaba; 10 = zelo dobra)), zadovoljstvo s političnim sistemom (demokracijo) v Sloveniji (»Kako ste na splošno zadovoljni z delovanjem demokracije v Sloveniji?« (o = izjemno nezadovoljen; 10 = izjemno zadovoljen)). Izobrazba je bila merjena na lestvici od o (brez šolske iz- 
obrazbe (o do največ 3 razredi osemletke ali do največ 5 razredov devetletke)) do 11 (doktorat).

V raziskavi Eurobarometer (Eurobarometer, 2019b) smo analizirali zadovoljstvo z delovanjem demokracije (»Gledano v celoti, kako ste zadovoljni $\mathrm{z}$ delovanjem demokracije $\mathrm{v}$ Sloveniji? « ( 1 = sploh nisem zadovoljen; $4=$ sem zelo zadovoljen)). Izobrazba je bila merjena v letih trajanja izobraževanja in rekodirana $v$ tri skupine $(1=$ do 15 let; $2=16-19$ let, $3=20$ let in več izobraževanja).

V raziskavi Stališča do cepljenja (Lamot in Kirbiš, 2019) smo merili naslednje dejavnike stališč do cepljenja: zaupanje v zdravstveni sistem, zaupanje $\mathrm{v}$ alternativno in komplementarno medicino ter prepričanje $\mathrm{v}$ teorije zarote. Zaupanje v zdravstveni sistem je bilo merjeno $s$ tremi trditvami (zadnji dve trditvi sta bili rekodirani): »Zdravstvo v Sloveniji skuša izboljšati zdravje pacientov po svojih najboljših močeh", "Zdravstvo v Sloveniji prikriva svoje napake « in "Zdravstvo v Sloveniji daje prednost dobičku pred potrebami pacientov $«(1=$ sploh se ne strinjam; $5=$ povsem se strinjam). Izdelali smo sumacijsko spremenljivko $\mathrm{z}$ visoko notranjo konsistentnostjo (Cronbachov $\alpha=0,85$ ).

Zaupanje $\mathrm{v}$ alternativno in komplementarno medicino je bilo merjeno s štirimi trditvami: »Pred odhodom k zdravniku je vselej vredno poskusiti s komplementarno in alternativno medicino «, »Komplementarna medicina in alternativna medicina vključujeta naravne rastlinske formule, ki so bolj zdrave od zdravil, ki jih predpiše zdravnik «, »Komplementarna in alternativna medicina sta praviloma boljša pot za zdravljenje bolezni« in »Komplementarno in alternativno medicino je treba uporabljati zgolj pri manjših težavah in ne pri zdravljenju resnejših bolezni« $(1=$ sploh se ne strinjam; $5=$ povsem se strinjam). Zadnji spremenljivki smo rekodirali vrednosti in nato izdelali sumacijsko spremenljivko, ki se je izkazala za visoko notranje konsistentno (Cronbachov $\alpha=0,87$ ).

Prepričanja $\mathrm{v}$ teorije zarote smo merili $\mathrm{z}$ dvema spremenljivkama: »Širjenje nekaterih virusov in bolezni je rezultat namernih, prikritih prizadevanj določenih organizacij« in »Fizični sledovi, ki jih letala puščajo v zraku (t. i. chemtrails) so kemične sledi oziroma kemično orožje « ( $1=$ sploh se ne strinjam; 5 = povsem se strinjam), iz katerih smo izdelali sumacijsko spremenljivko (Cronbachov $\alpha=0,84$ ). Izobrazbo smo ponovno merili na tristopenjski lestvici ( 1 - srednješolska izobrazba ali manj; 2 - dodiplomska izobrazba do vključno 1. bolonjske stopnje; 3 - dokončana 2. bolonjska stopnja ali višje). 
$\mathrm{V}$ raziskavi Stališča do epidemije covida-19 (Lamot in Kirbiš, 2020) smo merili tri dejavnike stališč do cepljenja. Zaupanje v zdravstveni sistem smo merili z enakimi tremi spremenljivkami kot v letu 2019 (Cronbachov $\alpha$ $=0,85)$. Zaupanje $\mathrm{v}$ alternativno in komplementarno medicino smo merili z dvema trditvama, enakima kot v letu 2019: »Komplementarna medicina in alternativna medicina vključujeta naravne rastlinske formule, ki so bolj zdrave od zdravil, ki jih predpiše zdravnik«, »Komplementarna in alternativna medicina sta praviloma boljša pot za zdravljenje bolezni« (Cronbachov $\alpha=0,91)$. Merili smo tudi percepcije tveganja oz. ogroženosti posameznika zaradi sezonske gripe in covida-19 $(1=$ sploh ni ogrožajoče; $5=$ zelo ogrožajoče). Prav tako smo s štirimi trditvami merili percipirano zaskrbljenost, da posameznik ali nekdo od njegovih bližnjih zboli za gripo ali covidom-19 (o = sploh me ne skrbi, 10 = zelo me skrbi).

\section{Rezultati}

Rezultati analiz podatkov Slovenskega javnega mnenja 2016/1 so pokazali, da sta bili ob kontroli spola in starosti $\mathrm{z}$ višjo stopnjo izobrazbe povezani dve izmed štirih preučenih spremenljivk: višja ocena kvalitete zdravstvenih storitev za otroke $\mathrm{v}$ kraju respondenta $(\mathrm{r}=0,10 ; \mathrm{p}<0,01)$ in večje zadovoljstvo $\mathrm{z}$ delovanjem demokracije v Sloveniji $(\mathrm{r}=0,07 ; \mathrm{p}<0,05)$.

Rezultati analiz podatkov (Eurobarometer, 2019b) so pokazali, da zadovoljstvo $z$ delovanjem demokracije ni povezano s stališči do cepljenja ( $p$ $>0,05)$.

Rezultati analiz podatkov raziskave Stališča do cepljenja (2019) so pokazali, da so ob kontroli spola in starosti z višjo stopnjo izobrazbe povezane vse tri preučene spremenljivke. Bolj izobraženi respondenti izkazujejo večje zaupanje $\mathrm{v}$ zdravstveni sistem ( $\mathrm{r}=0,15$; $\mathrm{p}<0,01)$, nižje zaupanje $\mathrm{v}$ alternativno in komplementarno medicino $(\mathrm{r}=-0,13 ; \mathrm{p}<0,01)$ in $\mathrm{v}$ manjši meri verjamejo v teorije zarote $(\mathrm{r}=-0,13 ; \mathrm{p}<0,001)$.

Ob kontroli spola in starosti se je v okviru analiz podatkov raziskave Stališča do epidemije covida-19 (2020) izkazalo, da so z višjo izobrazbo povezane tri spremenljivke: bolj izobraženi izkazujejo večje zaupanje v zdravstveni sistem $(\mathrm{r}=0,12 ; \mathrm{p}<0,01)$ in nižje zaupanje $\mathrm{v}$ alternativno in komplementarno medicino $(r=-0,13 ; \mathrm{p}<0,01)$, ob tem pa se jim covid-19 zdi bolj zdravju ogrožajoč $(\mathrm{r}=0,08 ; \mathrm{p}<0,05)$. 


\section{Razprava in sklep}

Namen naše raziskave je bil preučiti, ali je v Sloveniji izobrazba povezana $\mathrm{s}$ splošnimi stališči do cepljenja, $\mathrm{z}$ namero za cepljenje proti gripi in covidu-19 in z nekaterimi spremenljivkami, ki so se v preteklih raziskavah izkazale za dejavnike stališč do cepljenja. Izvedli smo tri študije na štirih vzorcih, od tega sta bila dva reprezentativna nacionalna vzorca.

Ključni sta predvsem dve ugotovitvi. Prvič, v Sloveniji stališča do cepljenja glede na naše analize niso povezana s stopnjo izobrazbe. To velja tako za splošna stališča do cepljenja kot za specifična stališča namere za cepljenje proti sezonski gripi in covidu-19. Drugič (in nekoliko neskladno s prvo ugotovitvijo), naše analize hkrati kažejo, da je izobrazba povezana s tistimi dejavniki stališč do cepljenja, ki so se v tujih raziskavah izkazali za statistično značilne. V Sloveniji bolj izobraženi izkazujejo višjo stopnjo zaupanja v zdravstveni sistem, so bolj zadovoljni $\mathrm{z}$ delovanjem političnega sistema in $\mathrm{v}$ večji meri percipirajo covid-19 (ne pa tudi gripe) kot ogrožajočo bolezen v primerjavi z manj izobraženimi družbenimi skupinami.

Možnosti za omenjeno nekonsistentnost je več. Ena možnost je, da nekateri dejavniki stališč do cepljenja, ki učinkujejo v tujih državah, ne učinkujejo v Sloveniji. Dosedanje raziskave v Sloveniji kažejo, da nekateri dejavniki v Sloveniji niso statistično značilni korelat stališč do cepljenja (gl. npr. Lamot, 2020), zato bi morale prihodnje raziskave preučiti, kateri dejavniki prispevajo k oklevanju Slovencev pred cepljenjem, vključno s cepljenjem proti covidu-19. Druga možnost je, da navkljub dejavnikom pozitivnih stališč do cepljenja (ti dejavniki so, kot smo ugotovili, v Sloveniji v večji meri prisotni med bolj izobraženimi) hkrati obstajajo tudi nekateri drugi korelati izobrazbe, ki so v večji meri prisotni med bolj izobraženimi in ki znižujejo pozitivna stališča do cepljenja. Primer takega dejavnika bi npr. lahko bil zdravizem (Swaney in Burns, 2019). Tudi to bi bilo potrebno podrobneje analizirati v prihodnjih raziskavah.

Sklenemo lahko, da v Sloveniji izobrazba nima enoznačne funkcije ozaveščanja o pomembnosti cepljenja in spodbujanja pozitivnih stališč do cepljenja (Lamot et al., 2021). Možno je, da izobraževalne institucije cepljenja, morda pa tudi drugih vidikov zdravih življenjskih stilov in z zdravjem povezanih stališč, ne vključujejo $\mathrm{v}$ zadostni meri v svoje kurikule. To je na ravni populacije sicer izguba potencialno pozitivnega učinka pomembnega družbenega vira - izobrazbe; navkljub večanju izobrazbenih ravni v Sloveniji v zadnjih desetletjih namreč obstaja precejšnja nenaklonjenost cepljenju in cepivom (Larson et al., 2016), tudi proti covidu-19 (Mediana, 2020; 
Valicon, 2020), četudi so cepiva eden najpomembnejših izumov sodobne znanosti in medicine (Orenstein in Ahmed, 2017). Zato ostaja pomembno, da tako zaposleni v izobraževalnih institucijah kot tudi javnozdravstvena stroka in politični odločevalci okrepijo izobraževalne programe in učinkovite komunikacijske strategije, ki bi pripomogli h krepitvi ozaveščanja javnosti o koristih in pozitivnih učinkih cepljenja proti preprečljivim nalezljivim boleznim ne zgolj za posameznika, ampak tudi za njegove bližnje in širšo družbo.

\section{Literatura}

Andre, F. E., R. Booy, H. L. Bock, J. Clemens, S. K. Datta, T. J. John, B. W. Lee et al. 2008. "Vaccination Greatly Reduces Disease, Disability, Death and Inequity Worldwide." Bulletin of the World Health Organization 86 (2): 140-46. https://doi.org/10.2471/blt.07.040089.

Beck, Ulrich. 1992. Risk Society: Towards a New Modernity. Theory, culture and society. London: Sage.

Betsch, Cornelia in Sabine Wicker. 2012. "E-Health Use, Vaccination Knowledge and Perception of Own Risk: Drivers of Vaccination Uptake in $\mathrm{Me}$ dical Students." Vaccine 30 (6): 1143-48. https://doi.org/10.1016/j.vaccine.2011.12.021.

Bloom, David, David Canning in Weston Mark. 2005. “The Value of Vaccination." World Economics 6 (3): 15-39.

Blume, Stuart. 2006. "Anti-Vaccination Movements and Their Interpretations." Soc. Sci. Med. 62 (3): 628-42. https://doi.org/10.1016/j.socscimed.2005.06.020.

Bocquier, Aurélie, Lisa Fressard, Sébastien Cortaredona, Anna Zaytseva, Jeremy Ward, Arnaud Gautier, Patrick Peretti-Watel in Pierre Verger. 2018. "Social Differentiation of Vaccine Hesitancy Among French Parents and the Mediating Role of Trust and Commitment to Health: A Nationwide Cross-Sectional Study.” Vaccine 36 (50): 7666-73. https://doi.org/10.1016/j. vaccine.2018.10.085.

Bocquier, Aurélie, Jeremy Ward, Jocelyn Raude, Patrick Peretti-Watel in Pierre Verger. 2017. "Socioeconomic Differences in Childhood Vaccination in Developed Countries: A Systematic Review of Quantitative Studies." Expert review of vaccines 16 (11): 1107-18. https://doi.org/10.1080/1476 0584.2017.1381020.

Browne, Matthew, Patricia Thomson, Matthew Justus Rockloff in Gordon Pennycook. 2015. "Going Against the Herd: Psychological and Cultural 
Factors Underlying the ,Vaccination Confidence Gap.” PLoS ONE 10 (9): e0132562. https://doi.org/10.1371/journal.pone.0132562.

Byrne, Claire, Jane Walsh, Susanna Kola in Kiran M. Sarma. 2012. "Predicting Intention to Uptake H1N1 Influenza Vaccine in a University Sample.” British journal of health psychology 17 (3): 582-95. https://doi.org/10.1111/j. 2044-8287.2011.02057.x.

Champion, Victoria L. in Celette Sugg Skinner. 2008. "The Health Belief Model." In Health Behavior and Health Education: Theory, Research, and Practice, edited by Karen Glanz, Barbara K. Rimer, and K. Viswanath. 4th ed., 45-65. San Francisco: Jossey-Bass.

Crawford, Robert. 1980. "Healthism and the Medicalization of Everyday Life." International journal of health services 10 (3): 365-88. https://doi. org/10.2190/3H2H-3XJN-3KAY-G9NY.

Dryhurst, Sarah, Claudia R. Schneider, John Kerr, Alexandra L. J. Freeman, Gabriel Recchia, Anne Marthe van der Bles, David Spiegelhalter in Sander van der Linden. 2020. "Risk Perceptions of COVID-19 Around the World." Journal of Risk Research 23 (7-8): 994-1006. https://doi.org/10.108 o/13669877.2020.1758193.

Edwards, Kathryn M. in Jesse M. Hackell. 2016. “Countering Vaccine Hesitancy." Pediatrics 138 (3). https://doi.org/10.1542/peds.2016-2146.

Ekram, Sahrish, Katherine E. Debiec, Megan A. Pumper in Megan A. Moreno. 2019. "Content and Commentary: HPV Vaccine and YouTube." Journal of pediatric and adolescent gynecology 32 (2): 153-57. https://doi.org/10.1016/j. jpag.2018.11.001.

Elizondo-Alzola, Usue, Mireia G. Carrasco, Laia Pinós, Camila Andrea Picchio, Cristina Rius in Elia Diez. 2020. Vaccine Hesitancy Among Pediatric Nurses: Prevalence and Associated Factors: Research Square.

Endrich, Michael M., Patricia R. Blank in Thomas D. Szucs. 2009. "Influenza Vaccination Uptake and Socioeconomic Determinants in 11 European Countries." Vaccine 27 (30): 4018-24. https://doi.org/10.1016/j.vaccine.2009.04.029.

eUprava. “Zbiranje Interesa Državljanov Za Cepljenje Proti Covid-19.” Accessed December 16, 2020. https://e-uprava.gov.si/podrocja/sociala-zdravje-smrt/zdravje/vloga-cepljenje.html.

Eurobarometer. 2019a. "Eurobarometer 91.2 [Dataset]: Special Eurobarometer 488 - Wave EB91.2 - Kantar.” Accessed December 16, 2020. https://dbk. gesis.org/dbksearch/SDesc2.asp?DB $=\mathrm{E} \&$ no $=7562$. 
Eurobarometer. 2019b. “Europeans' Attitudes Towards Vaccination: Report: Special Eurobarometer 488 - Wave EB91.2 - Kantar.” Accessed December 16, 2020. https:/ec.europa.eu/health/sites/health/files/vaccination/ docs/20190426_special-eurobarometer-sp488_en.pdf.

Fontanet, Arnaud in Simon Cauchemez. 2020. "COVID-19 Herd Immunity: Where Are We?” Nature reviews. Immunology 20 (10): 583-84. https://doi. org/10.1038/s41577-020-00451-5.

Gallup. 2019. "Wellcome Global Monitor: How Does the World Feel About Science and Health?” Accessed November 12, 2019. https://wellcome.ac.uk/ sites/default/files/wellcome-global-monitor-questionnaire-development-

Greenhalgh, Trisha in Simon Wessely. 2004. “Health for Me': A Sociocultural Analysis of Healthism in the Middle Classes." British medical bulletin 69:197-213. https://doi.org/10.1093/bmb/ldho13.

Healy, Mary C. 2014. "Commentary on "Parental Vaccine-Hesitancy: Understanding the Problem and Searching for a Resolution".” Human Vaccines \& Immunotherapeutics 10 (9): 2597-99. https://doi.org/10.4161/2164 5515.2014 .970074 .

Hoffman, Beth L., Elizabeth M. Felter, Kar-Hai Chu, Ariel Shensa, Chad Hermann, Todd Wolynn, Daria Williams in Brian A. Primack. 2019. "It's Not All About Autism: The Emerging Landscape of Anti-Vaccination Sentiment on Facebook." Vaccine 37 (16): 2216-23. https://doi.org/10.1016/j.vaccine.2019.03.003.

Hornsey, Matthew J., Emily A. Harris in Kelly S. Fielding. 2018. "The Psychological Roots of Anti-Vaccination Attitudes: A 24-Nation Investigation.” Health psychology 37 (4): 307-15. https://doi.org/10.1037/heaoooo586.

Inglehart, Ronald in Christian Welzel. 2005. Modernization, Cultural Change, and Democracy: The Human Development Sequence / Ronald Inglehart, Christian Welzel. Cambridge: Cambridge University Press.

Jehn, Anthony in Anna Zajacova. 2020. COVID-19 Health Precautions: Examining Demographic and Socioeconomic Disparities.

Jolley, Daniel in Karen M. Douglas. 2014. "The Effects of Anti-Vaccine Conspiracy Theories on Vaccination Intentions.” PLoS ONE 9 (2): e89177. https:// doi.org/10.1371/journal.pone.0089177.

Kavanagh, Nolan M., Rishi R. Goel in Atheendar S. Venkataramani. 2020. Association of County-Level Socioeconomic and Political Characteristics with Engagement in Social Distancing for COVID-19: Cold Spring Harbor Laboratory. 
Kirbiš, Andrej, Helena Hrženjak, Jure Koražija, Katja Kerman in Monika Lamot. 2020. “The Politicization of Attitudes Towards Preventive Behavior and Vaccine Acceptance During the First Wave of the COVID-19 Pandemic in a Post-Socialist European Country: The Case of Slovenia.” https:// www.researchgate.net/publication/346542926_The_Politicization_of_ Attitudes_Towards_Preventive_Behavior_and_Vaccine_Acceptance_ during_the_First_Wave_of_the_COVID-19_Pandemic_in_a_Post-Socialist_European_Country_the_Case_of_Slovenia_Politizacija.

Kurdija, Slavko, Mitja Hafner Fink, Brina Malnar in Klement Podnar. 2016. “Slovensko javno mnenje 2016/1.”.

Lalumera, Elisabetta. 2018. “Trust in Health Care and Vaccine Hesitancy.” estetica, no. 68: 105-22. https://doi.org/10.400o/estetica.3553.

Lamot, Monika. 2020. "Determinants of Vaccine Attitudes [Master Thesis].”.

Lamot, Monika, Marija Javornik Krečič in Andrej Kirbiš. 2021. "Impact of Education on Vaccination Knowledge and the COVID-19 Vaccine Uptake Intention in Slovenia: Does Trust in the Healthcare System Moderate the Effects?" Sodobna Pedagogika 72: 108-28.

Lamot, Monika in Andrej Kirbiš. 2019. "Stališča Do Cepljenja V Letu 2019 [Dataset].” Accessed December 16, 2020.

Lamot, Monika in Andrej Kirbiš. 2020. "Stališča Do Covid-a [Dataset].” Accessed December 16, 2020.

Larson, Heidi J., Alexandre de Figueiredo, Zhao Xiahong, William S. Schulz, Pierre Verger, Iain G. Johnston, Alex R. Cook in Nick S. Jones. 2016. “The State of Vaccine Confidence 2016: Global Insights Through a 67-Country Survey." EBioMedicine 12:295-301. https://doi.org/10.1016/j.ebiom.2016.08.042.

MacDonald, Noni E. 2015. "Vaccine Hesitancy: Definition, Scope and Determinants." Vaccine 33 (34): 4161-64. https://doi.org/10.1016/j.vaccine.2015.04.036.

Malik, Amyn A., SarahAnn M. McFadden, Jad Elharake in Saad B. Omer. 2020. "Determinants of COVID-19 Vaccine Acceptance in the US." EClinicalMedicine, 100495. https://doi.org/10.1016/j.eclinm.2020.100495.

Martinello, Richard A., Laura Jones in Jeffrey E. Topal. 2003. "Correlation Between Healthcare Workers' Knowledge of Influenza Vaccine and Vaccine Receipt." Infect. Control Hosp. Epidemiol. 24 (11): 845-47. https://doi. org/10.1086/502147.

Mediana. 2020. "Mediana: Oktobra Bi Se Proti Koronavirusu Cepilo Manj Ljudi Kot Junija.” Accessed October 15, 2020. https://www.24ur.com/novice/ 
slovenija/mediana-oktobra-bi-se-proti-koronavirusu-cepilo-manj-ljudi-kot-junija.html.

Novella, Steven. 2007. “The Anti-Vaccination Movement.” Skeptical Inquirer 31 (6): 25-38.

Orenstein, Walter A. in Rafi Ahmed. 2017. "Simply Put: Vaccination Saves Lives." Proceedings of the National Academy of Sciences of the United States of America 114 (16): 4031-33. https://doi.org/10.1073/pnas.1704507114.

OurWorldinData. 2020. "Slovenia: Coronavirus Pandemic Country Profile." https://ourworldindata.org/coronavirus/country/slovenia.

Ratej, Maja in Zarja Muršič. 2020. "Cepljenje Obvarovalo Milijardo in Pol Človeških Življenj.” Accessed December 16, 2020. https://www.rtvslo.si/ zdravje/cepljenje-obvarovalo-milijardo-in-pol-cloveskih-zivljenj/5446o8.

Rozbroj, Tomas, Anthony Lyons in Jayne Lucke. 2019. "Psychosocial and Demographic Characteristics Relating to Vaccine Attitudes in Australia." Patient education and counseling 102 (1): 172-79. https://doi.org/10.1016/j. pec.2018.08.027.

Swaney, Sharon Elizabeth in Sharyn Burns. 2019. "Exploring Reasons for Vaccine-Hesitancy Among Higher-SES Parents in Perth, Western Australia." Health promotion journal of Australia: official journal of Australian Association of Health Promotion Professionals 30 (2): 143-52. https://doi. org/10.1002/hpja.19o.

Valicon. 2020. "Več Kot Polovica Prebivalcev Se Ne Namerava Cepiti, Ko Bo Cepivo Na Voljo.” Accessed December 12, 2020. https://www.rtvslo.si/ slovenija/raziskava-vec-kot-polovica-prebivalcev-se-ne-namerava-cepiti-ko-bo-cepivo-na-voljo/542471.

van der Schee, Evelien in Peter P. Groenewegen. 2010. "Determinants of Public Trust in Complementary and Alternative Medicine." BMC public health 10:128. https://doi.org/10.1186/1471-2458-10-128.

Ward, Jeremy Keith, Caroline Alleaume in Patrick Peretti-Watel. 2020. “The French Public's Attitudes to a Future COVID-19 Vaccine: The Politicization of a Public Health Issue.” https://doi.org/10.31235/osf.io/xphe9.

WHO. 2019. “Ten Threats to Global Health in 2019.” Accessed March 30, 2020. https://www.who.int/news-room/feature-stories/ten-threats-to-global-health-in-2019.

Wolfe, Robert M. in Lisa K. Sharp. 2002. "Anti-Vaccinationists Past and Present.” BMJ 325 (7361): 430-32. https://doi.org/10.1136/bmj.325.7361.430. 
World Economic Forum. 2020. "These Discoveries Saved Billions of Lives." Accessed December 16, 2020. https://www.weforum.org/agenda/2018/o3/ the-50-most-important-life-saving-breakthroughs-in-history.

Zingg, Alexandra in Michael Siegrist. 2012. "Measuring People's Knowledge About Vaccination: Developing a One-Dimensional Scale." Vaccine 30 (25): 3771-77. https://doi.org/10.1016/j.vaccine.2012.03.014. 